\title{
INNOVATION OF NATURAL MOSQUITO REPELLENT PRODUCTS (AMUK CANDLE) AS THE OPPORTUNITY FOR COMMUNITY BUSINESS
}

\author{
Harefan Arief, Eko Tama Putra Saratian, Dudi Permana, Mochamad Soelton, and \\ Fatchur Rohman, Mugiono \\ Universitas Mercu Buana Jakarta, Indonesia \\ Universitas Brawijaya, Indonesia.
}

\begin{abstract}
Often the word innovation is associated with the word invention. According to Drucker (1985), Innovation is a special tool in exploiting changes in various businesses and services. He added, this innovation can be presented as a discipline that can be learned and practiced. In other words, innovation is also said to be "an idea, practice, or object that is considered new by other individuals or adoption units" (Daugherty et al., 2011; Grawe, 2009; Rogers, 1995). Meanwhile, Tidd, Bessant, Pavitt, and Wiley (1998) define innovation as the process of turning opportunities into fresh ideas and being widely used in practice. Global Entrepreneurion Monitor (GEM), reports that entrepreneurship is now the main stage in the arena of public policy in most countries. As social, environmental and economic challenges face humanity, many people believe that business has an important role to play in transforming society in the future. Entrepreneurs are considered to have a special role in innovation and bringing social change, traditionally from a macroeconomic perspective (Bosma et al, 2012). The field of innovation is very broad. The ability to develop new ideas and innovations has become a priority for many organizations. Intense global competition and technological developments have made innovation a reality a source of competitive advantage. The ability of an entrepreneur to put forward the idea of a higher value can be a source of competitive advantage. Entrepreneur that can create competitive advantage are able to increase their activities with the experience gained, by the knowledge gained, over time, it may be a source of distinctive competence in the market.
\end{abstract}

Key words: Competition Advantage, Environmental, Entrepreneur, Innovation

\section{INTRODUCTION}

Indonesia is a tropical country, the warmer weather conditions brought by the El Nino phenomenon encourage the breeding and maturation of the Aedes Mosquito population to be faster. This caused an explosion of mosquito populations in tropical regions such as Indonesia. Furthermore, countries with both rainy and hot weather conditions can make mosquito eggs hatch well and on time. Just the small amount of water needed to incubate an Aedes Mosquito.

Anopheles and Culex mosquito bites at night can potentially disturb the occupants of the house during breaks, or dinner in restaurants, while Aedes mosquitoes bite in the morning and often interfere with the occupants during their morning activities or employees who are working. At each mosquito cycle, it can put us at risk of contracting diseases caused by mosquitoes, such as the Aedes mosquito, which carries dengue fever, Anopheles mosquitoes carrying Malaria and Mosquito Cules carrying Enfasalitis B disease from Japan.

Mosquitoes are one of the dangerous insects, because mosquitoes can cause diseases that can cause a person to die. Some mosquitoes are capable of spreading protozoan diseases such as malaria, filaria diseases such as elephantiasis, and viral congenital diseases such as yellow fever, dengue hemorrhagic fever, encephalitis, and West Nile virus. The West Nile virus was accidentally spread to the United States in 1999 and in 2003 it has spread to all states in the United States. Therefore many people choose to eradicate this insect.

Keep in mind there are so many ways to avoid and even eradicate mosquitoes, including making mosquito traps such as making traps from plastic bottles filled with sugar solution, spreading odors around the room or doing fogging, smearing the body with anti-mosquito lotion.

In the past before modern mosquito repellent devices were found, people often used natural ingredients and traditional methods to repel and even eradicate mosquitoes. Usually they use smells that mosquitoes don't like such as lemongrass stems, dried orange peels, lemons. Usually people will cut the lemongrass stems and then 
stick them into lime which has been cut into two parts, this method is proven effective to repel mosquitoes, but the material does not last long, because the material is easy to rot.

Indonesia is a country rich in spices, so spices are very easy to obtain. Whatever the type of natural ingredients, if processed properly it will produce optimal results and can be used as an alternative choice to substitute modern products that are available today. These natural ingredients have been proven to be good and safe to use in the long term.

Therefore we try to make mosquito repellent that is natural, environmentally friendly and does not have a bad effect on health. By making candles that are made from natural and proven effective can repel mosquitoes. Actually we have made several tests such as making ointments or topical cream for mosquitoes, but because everyone has different skin types, we therefore chose to make aroma candles to repel mosquitoes.

\section{THEORETICAL FRAMEWORK}

Often the word innovation is associated with the word invention. According to Drucker (1985), Innovation is a special tool in exploiting changes in various businesses and services. He added, this innovation can be presented as a discipline that can be learned and practiced. In other words, innovation is also said to be "an idea, practice, or object that is considered new by other individuals or adoption units" (Daugherty et al., 2011; Grawe, 2009; Rogers, 1995). Meanwhile, Tidd, Bessant, Pavitt, and Wiley (1998) define innovation as the process of turning opportunities into fresh ideas and being widely used in practice. Quite similar to Bentz (1997) who assume that innovation is to issue new processes, services or products for marketing. Afuah (1998) suggests innovation is "the use of new technical and administrative knowledge to offer new products or services to customers". As such, many authors conclude that innovation is "whatever practices are new to organizations, including equipment, products, services, processes, policies, and projects" (Damanpour, 1991; Kimberly \& Evanisko, 1981; Lin, 2007).

Khazanchi, Lewis, and Boyer (2007) also extend the conclusion where they say that innovation is one of the main relevance for companies, because it can be a source of additional revenue from new products or services, can help save costs or improve quality. from the existing process. Meanwhile, Wang and Ahmed (2004) define innovation as "the overall innovative ability of organizations to introduce new products to the market, or open new markets, by combining strategic orientation with innovative behavior and processes . Hult et al. (2004) then adds that innovation seems to be useful in helping companies to compete with competitors with new or improved products and verifying product lines, but expanding the range of company activities in general.

Global Entrepreneurion Monitor (GEM), reports that entrepreneurship is now the main stage in the arena of public policy in most countries. As social, environmental and economic challenges face humanity, many people believe that business has an important role to play in transforming society in the future. Entrepreneurs are considered to have a special role in innovation and bringing social change, traditionally from a macroeconomic perspective (Bosma et al, 2012).

The inclusion of sustainability in entrepreneurial activities makes this in the entrepreneurship literature, ensuring that it remains an additional aspect rather than an integrative aspect of entrepreneurship. Much of the company's sustainability research has focused on the economic and environmental dimensions of sustainability. One study that has explored the issue of sustainability holistically is Klapper and Upham (2015). They examine how the daily practices of small and micro companies simultaneously reach various dimensions of sustainability. They create models of micro enterprise entrepreneurial relationships and value creation with economic, social and environmental aspects of sustainable development.

\section{METHOD}

The method applied is to design and manufacture products in the form of mosquito repellent that is friendly to the environment by using materials that are around us. The use of natural ingredients that have been known by the ancestors.

Mosquito repellent wax is made so that it can be easier to avoid mosquito bites. In addition to the presence of mosquitoes that are very disturbing, mosquitoes can also cause several types of diseases. Although some factories already produce modern mosquito repellent drugs made from DEET chemical. and world health agencies recommend the use of DEET, sometimes DEET causes health and environmental problems. Therefore we want to create mosquito repellent products from natural ingredients without disturbing health and the environment. 


\section{BASIC MATERIAL}

We have selected a number of spices as the basic ingredients, including lemongrass and turmeric, as well as orange and lemon peels. The benefits of lemongrass oil are similar to DEET in inhibiting mosquito olfactory sensors. Lemongrass oil works to mask the attractive aroma to insects, carbon dioxide and lactic acid in the human body. Lemongrass oil is favored as a safer alternative to generic mosquito repellent, because it contains natural active ingredients that can fight the effects of free radicals so it does not harm the body.

Research says that how to mix lemongrass oil is important to determine how effective a mosquito repellent product is. If the lemongrass oil product is formulated correctly, it will be as effective as DEET lotion and can protect you for up to two hours. If the formula is incorrect, lemongrass oil can evaporate quickly and make it unprotected.

Therefore we add some other ingredients such as orange and lemon zest. in orange and lemon peels, there is a substance called limonene with a percentage of 92-94 percent. This substance functions as an anti mosquito because it can kill mosquitoes.

Mosquitoes don't like bright colors like yellow. Here we can use turmeric as a yellow coloring agent in candles

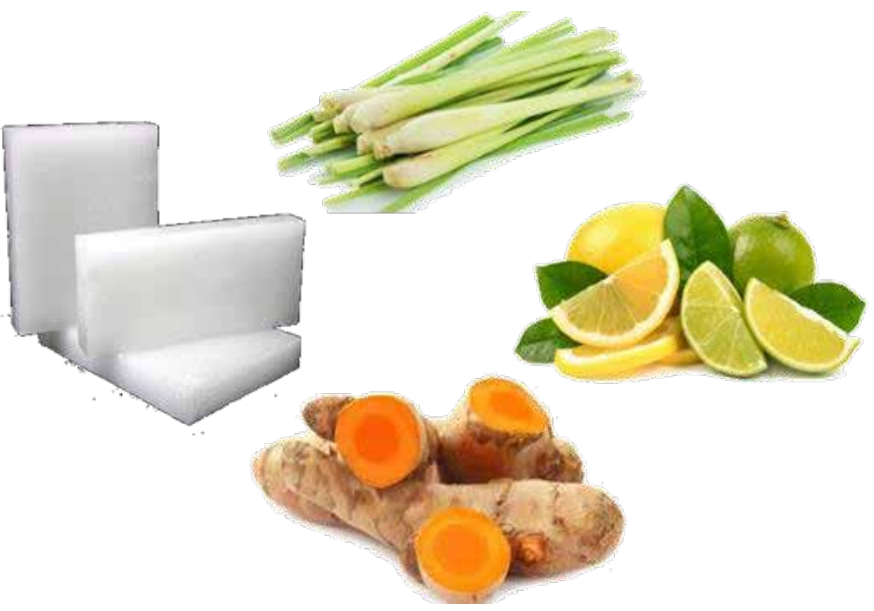

\section{MANUFACTURE}

The manufacturing process is done as soon as all the necessary ingredients are collected such as paraffin, lemongrass, lemon and turmeric. We also prepared a variety of other equipment such as molds or containers for candles, stoves and pans for melting paraffin, yarn as a candle wick, and various other dry ingredients in addition to candles such as cinnamon, orange peel, cloves and dried flowers.

First we prepare the lemongrass to make oil extracts as the main ingredient of wax, then we don't forget to set aside some of the lemongrass to be dried for decoration as a candle. Then we also cut the lemon to take the juice and some to dry, not forgetting the skin, we set it aside as an additional wax. Then we also refine turmeric to take the juice to be used as a natural dye in wax.

The next step is the melting process of the parrafin, before we cut the paraffin to a smaller size so as to facilitate the melting process. This was done because the paraffin was a solid object so we decided to cut the paraffin into smaller sizes before we melted it in the pan. When parrafin is completely melted, then we add lemon grass extract and grated lemon peel, then stir until evenly distributed.

Then we prepare a container or mold for the candle dough. First the container is cleaned then we put a piece of yarn that will be used as the wick on the candle later. After that the mixture is poured into a container, then let stand until the dough hardens and is ready to use. 


\section{RESULTS AND DISCUSSION}

When the manufacturing process is successful the next step is the testing phase. At this stage we tested the ability of candles to ward off mosquitoes. And the results can be said to be successful, the aroma emitted from the candles managed to repel mosquitoes, the aroma was not too pungent as products that use DEET ingredients so that the candle is considered safe to use. 1 candle can be used for 1 room . P roduk this we consider successful the next stage is the process of printing and provision of additional ornaments to beautify the look of candles. Previously, we made a wax dough, only the difference was in the printing process.

At this stage the wax mixture that has been poured in the container will be given additional decorations such as dried orange peel, dried lemon slices, cinnamon sticks and some other dried herbs. The process of laying additives is done when the wax mixture is not fully dense and hardened.

Entrepreneurship is the process of creating something new and making something different from what already exists, and aims to achieve prosperity for themselves and for society (Kao, 2002). Entrepreneurs are considered to have a special role in innovation and bringing social change, traditionally from a macroeconomic perspective (Bosma et al, 2012). According to Simamora in Sinta (2004), new products are goods and services that are basically different from those previously marketed by companies. New product development is the process of finding ideas for new goods and services and converting them into additional commercially successful product lines .

\section{CONCLUSION}

Innovation is an important element in today's world because products, services and technology move faster in the hearts of customers, resulting in benefits and profits that cannot be solved for companies and businesses. Innovation, which is usually defined to create or improve products or services to produce something new, has been started a long time ago, and has been implemented by many successful companies so that they can compete with other existing competitors. Product innovation is represented by new products or services that are introduced to meet the needs of the market. Such innovation is reflected in the new products or services on the market for the benefit of customers

The field of innovation is very broad. The ability to develop new ideas and innovations has become a priority for many organizations. Intense global competition and technological developments have made innovation a source of competitive advantage. The ability of an entrepreneur to put forward the idea of a higher value can be a source of competitive advantage . Companies that can create competitive advantage are able to increase their activities with the experience gained, by the knowledge gained, over time, it may be a source of strong competence in the market.

\section{REFERENCES}

Al Manun, Abdullah. Fajrah, Siti. Noorshella and Zakaria, (2017) Factors affecting entrepreneurial intention among Malaysian University Student, The journal of developing areas, Vol.51 No.6

Boer, Harry. (2001). Innovation, What Innovation? A Comparison between product, process and organizational innovation. International Journal of Technology Management - INT J TECHNOL MANAGE. 22. 83-107. 10.1504/IJTM.2001.002956.

Bosma, N.S., Wennekers, S. and Amorós, J.E. (2012). Global Entrepreneurship Monitor 2011 Extended Global Report: Entrepreneurs and entrepreneurial employees across the globe, Babson Park, MA, US: Babson College, Santiago, Chile: Universidad del Desarollo, Kuala Lumpur, Malaysia: Universiti Tun Abdul Razak and London, UK: Global Entrepreneurship Research Association.

Damanpour, F. (1991). Organizational innovation: A meta-analysis of effects of determinants and moderators. Academy of Management Journal, 34(3), 555-590. http://dx.doi.org/10.2307/256406

Drucker, P. (1985). Innovation and Entrepreneurship. (MA), Cambridge

Hult, G. T. M., Hurley, R. F., \& Knight, G. A. (2004). Innovativeness: Its antecedents and impact on business performance. Industrial Marketing Management, 33(5), 429-438.

Khazanchi, S., Lewis, M. W., \& Boyer, K. K. (2007). Innovation-supportive culture: The impact of organizational values on process innovation. Journal of operations management, 25(4), 871-884. http://dx.doi.org/10.1016/j.jom.2006.08.003 
Kimberly, J. R., \& Evanisko, M. J. (1981). Organizational innovation: The influence of individual, organizational, and contextual factors on hospital adoption of technological and administrative innovations. Academy of Management Journal, 24(4), 689-713. http://dx.doi.org/10.2307/256170

Lin, C. Y. (2007). Factors affecting innovation in logistics technologies for logistics service providers in China. Journal of Technology Management in China, 2(1), 22-37. http://dx.doi.org/10.1108/17468770710723604

Lin, C. (2006). A study on the organizational innovations in Taiwan's logistics industry. The Business Review, Cambridge, 5(1), 270.

Marjuki, Ismail (2009),’Daya bunuh beberapa obat nyamuk bakar terhadap kematian nyamuk Anopheles Aconicus"

M.Z, Nur \& Abdul Wahab, Prof Dr Sazali \& Mamun, Abdullah \& Yaacob, Abu \& Kumar, Naresh \& Fazal, Syed. (2016). Defining the Concept of Innovation and Firm Innovativeness: A Critical Analysis from Resorce-Based View Perspective. International Journal of Business and Management. 11. 87-94. 10.5539/ijbm.v11n6p87.

Soelton, Mochamad, Nugrahati, Tati, 2018. How Complaining Behaviors Effect on Coping Stress and Anxiety?. International Journal of Saudi Journal of Business and Management Studies (SJBMS). Vol. 3, No. 6. 623628.

Soelton et al, 2019. Gender : Stress Levels On Performance In Modern Industry. International Journal Archives of Business Research (United Kingdom). Vol. 7, No 2. 72-81

Soelton et al, 2018. Toward The Best Strategy In Minimizing The Spread of Drug Users. International Conference On Community Development In Asia. Vol 1. No 1. 171-176

Wijaya H. M. Hembing (1992), ’Tanaman Berkhasiat Obat di Indonesia”, Cet 1 ,Jakarta 